\title{
ANTI-AVOIDANCE LEGISLATIONS: ISSUES \& DOUBTS IN THE APPLICATION OF TAX RULES IN NIGERIA
}

\author{
M.T. Abdulrazaq ${ }^{1}$ \\ K.I. Adam ${ }^{2}$ \\ Professor Muhammed Taofiq AbdulRazaq \\ LL.B, PhD (ABU), LL.M (Lond.), B.L. FCII, FCIB. Professor of Revenue Law, Faculty of \\ Law, Lagos State University, Lagos, Nigeria and can be reached by email @ \\ mtabdulrazaq@gmail.com.; Hand Phone No. +2348179033202 \\ Dr. Kayode Ibrahim Adam \\ LL.B (BUK), LL.M (OAU), Ph.D. (IIU, Malaysia), Senior Lecturer, Department of Business \\ Law, University of Ilorin, Ilorin, Nigeria and can be reached by email @ \\ adam kayus2003@yahoo.com; .; Hand Phone No. +2347056125875
}

Abstract

For close to what seems a millennium, tax avoidance activities have plagued global tax jurisprudence especially in Nigeria where legislative and judicial solutions to it have remained illusory. This paper represents an attempt to analyse issues and doubts that trail the application of anti-avoidance provisions in Nigeria.

Keywords: tax avoidance, anti-avoidance provisions, fictitious transactions, characterization of facts, preplanned events, substance over form

\section{$1 \quad$ Introduction}

It is fit and proper in the course of the millennium to take stock of an issue that has plagued tax jurisprudence since 1936 and Nigerian tax law since 1961 when the Income Tax Management Act was promulgated ${ }^{3}$. The purpose of this work therefore is to attempt a comparative analysis of anti-avoidance legislations and its application in the light of the present nature of tax law in Nigeria. ${ }^{4}$

\section{$2 \quad$ Anti-Avoidance Legislations}

Anti-avoidance legislations are statutory provisions which seek to prevent an escape from liability to tax payer using artificial or fictitious transactions to dodge tax. The escape of liability usually involves no criminality. ${ }^{5}$

Anti-avoidance legislations are fairly common in most countries and the following are examples of countries where they are applicable. ${ }^{6}$

1 LL.B, PhD (ABU), LL.M (Lond.), B.L. FCII, FCIB. Professor of Revenue Law, Faculty of Law, Lagos State University, Lagos, Nigeria and can be reached by email @ mtabdulrazaq@gmail.com.

2 LL.B (BUK), LL.M (OAU), Ph.D. (IIU, Malaysia), Senior Lecturer, Department of Business Law, University of Ilorin,Ilorin, Nigeria and can be reached byemail @ adam_kayus2003@yahoo.com.

3 See section 14 of the 1961 (ITMA)

4 See generally Abdulrazaq M.T. (1991) Legislation Against Tax Avoidance: The Nigeria Experience Justice: Journal of Contemporary Legal Problems Vol.2 No.9 pp.33-46 (Federal Ministry of Justice).

5 Abdulrazaq M.T. (1992) The Legal Nature of Tax Evasion and Avoidance, Nigerian Financial Review Vol.4. No.3 pp.65-74 (Infodata Publication).

$6 \quad$ See Tax Law in the Melting Pot (1985) Appendix 1 (The law Society of England and Wales). 


\subsection{Australia}

\section{(a) Fiscal Background}

Australia is a federation comprising six states and two federal territories, plus, external territories. Tax is imposed at both state and federal level.

Domestic federal taxation is imposed on income; the government has introduced an indexed capital gains tax in respect of capital gains on assets acquired after 19 September 1985, at normal personal and corporate income tax rates (death will not constitute a deemed disposal); there is no wealth tax or tax on estates, inheritances or gifts. There is no stamp duty at the federal level on transfers of property; customs duty and sales tax are charged at federal level.

\section{(b) Anti-Avoidance Legislation}

A general anti-avoidance provision has been comprised in the income tax legislation since the last century. Its scope has largely been determined by judicial interpretation; and judicial attitudes, as exemplified by judicial interpretation have varied over the years. However, the existence of such a provision has meant that it has not been necessary for the judiciary to incorporate into Australian tax law without statutory justification the equivalent of a general, anti-avoidance provision, by the adoption of any general doctrine such as bona fide business purpose test, abuse of rights, substance versus form or similar. No such general concept has as such been imposed by the courts and the anti-avoidance provisions contained in statute are not drafted is such terms nor, until recently, have the tax authorities sought to have such a general concept imposed. In the last few authorities sought to have such a general concept imposed. In the last few years, however, inspired by Ramsay and other UK cases, the Commissioner has argued flor similar principles to be applied in Australia, so far without success. Nevertheless the interpretation over the years of the general anti-avoidance provisions has resulted in an approach not dissimilar to a "Business purpose" test being hitherto adopted in many cases in determining whether such provisions were applicable.

\subsection{Canada}

\section{(a) Fiscal Background}

Canada is a federation comprising provinces. Tax is imposed at both provincial and federal taxation level. The dominant tax in Canada is income tax. Capital gains tax (which is levied on emigration, gifts and death as well as on sales) is in effect levied as income tax by the inclusion of half the gain in the taxpayer's income, other half being exempt. Corporations are taxed to income tax and not to a separate corporation tax. Tax levied on non-residents of Canada in respect of Canadian income is notionally a separate tax but it is based on income tax principles. There is no wealth tax, and the estate duty and gifts tax have been abolished.

Other than Quebec, the provinces have legal systems largely based on that of the UK. Many of the concepts of UK law have been transposed into Canadian law. Quebec, with its French origins, has a civil law system including the concept of abuse of rights. Canadian revenue law has however been dominated by federal legislation and nothing has shown that the law of Quebec has been of any significant contribution to Canadian jurisprudence in strictly fiscal matters.

\section{(b) Anti-Avoidance Legislation}

Canadian law has a general provision nullifying artificial transactions, there being no statutory definition of "artificial". Section 245 (1) of the Income Tax Act, set out below is however, by no means universally invoked by Revenue Canada:

In computing income for the purpose of this Act, no deduction may be made in respect of a disbursement or expense made or incurred in respect of a transaction or operation that, if allowed, would unduly or artificially reduce the income. 


\section{M.T. Abdulrazaq K.I. Adam}

\subsection{New Zealand}

(a) Fiscal Background

New Zealand is a non-federal country and therefore domestic taxation (properly so-

called) is imposed on a national basis only. Domestic taxation is imposed on income, but not on capital gains, although various provisions in the tax legislation effectively imposed income tax on what could be regarded as capital gains. There is no wealth tax, but there is a tax on estates, inheritances and gifts. There is also stamp duty calculated by references to the value of property transferred.

\section{(b) Anti-Avoidance Legislation}

There is a general anti-avoidance provision in the New Zealand Income Tax Legislation; currently section 99 Income Tax 1976. A similar provision dates back to the early part of the last century. In addition, there are what may be called specific anti-avoidance provisions in the legislations: For example, the provision permitting relief corresponding to UK group relief contain provisions intended to prevent tax avoidance schemes designed to enable that relief to be claimed.

Section 99 Income Tax Act 1976 was first enacted in its present form in 1974, replacing the former section 108 of the Land \& Income Tax Act 1954. It provides (section 99 (2)) that:

Every arrangement made or entered into... shall be absolutely void as against the Commissioner for income tax purposes if and to the extent that, directly or indirectly:

a. its purpose or effect is tax avoidance a defined term in section 99 (1); or

b. where it has two or more purposes or effects, one of its purposes (not

being a merely incidental purpose or effect) is tax avoidance, whether or not

any other or others of its purposes or effect relate to or are referable to

ordinary business or family dealings...

It also provides that the assessable income of any person affected by an arrangement avoided under Section 99(2) shall be adjusted "in such manner as the Commissioner considers appropriate so as to counteract any tax advantage obtained by that person from or under that arrangement....." (Section 99 (3)).

The replaced section 108 provided more simply that a contract, agreement or arrangement was void as against the commissioner "so far as, directly or indirectly, it has or purports to have the purpose or effect of in any way altering the incidence of income tax or relieving any person from his liability to pay income tax"

\section{$2.4 \quad$ United States}

\section{(a) Fiscal Background}

The United States is a federation comprising fifty states and the federal District of Colombia plus external possessions. Tax is imposed at both state and federal level, and also by some municipalities.

Domestic federal taxation is imposed on income and capital gains, on estates and generation skipping transfers, and no gifts. There is no wealth tax. There are federal excise taxes on sales of certain commodities. At federal level there are no stamp duties.

\section{(b) Anti-Avoidance Legislation}

There are numerous anti-avoidance provisions in the Tax Code. For example, the Secretary of the Treasury or his delegate may (i) under section 482 of the Code reallocate income and deductions among related parties in order to prevent evasion or clearly to reflect the income of the parties and (ii) under section 845 (b) may make proper adjustment", in calculating the income of an insurance, company, for any reinsurance contract having "a significant tax avoidance effect". Extensive regulations have been issued under section 482, which provide safe-harbours and other forms of protection against the exercise of unfettered 


\section{ANTI-AVOIDANCE LEGISLATIONS: ISSUES \& DOUBTS IN THE APPLICATION \\ OF TAX RULES IN NIGERIA}

discretion. The Congressional Joint Committee on Taxation has described factors that should be taken into account in making the determination whether a significant tax avoidance effect exists, and those factors are incorporated regulations.

\section{$3 \quad$ Applying the Anti-Avoidance Legislation}

The traditional analysis of the legal function, and especially the judicial function, is in three parts -finding the facts, interpreting the law and applying the law as determined to the facts as discovered. In the Nigerian tax appeal system the first layer are the Appeal Commissioners, who do all three things, and the courts to which appeals lie, which can intervene only where threw is error of law and which therefore have no role in the determination of the facts. Of these three parts the third is perhaps the most interesting and certainly the least consciously analysed. What the courts are doing is determining the tax characterization of the facts with which they have been presented ${ }^{7}$.

A major issue in the characterization of the facts is the extent to which the courts can take account of tax avoidance purposes. Related to this is the primary question of authority, that is the legal justification, for may particular anti-avoidance approach. Tax avoidance, which is lawful, must be distinguished from tax evasion, which is illegal. If a person marries in order to reduce his tax burden he is practicing tax avoidance; if he tells the tax authorities that he is married when he is not, he guilty of tax evasion, and may well be prosecuted. There is also an important distinction between a scheme under which no liability to tax arises - tax avoidanceand one under which a charge arises but the tax cannot be collected ${ }^{8}$.

The distinction between avoidance and evasion in Nigerian was first raised in the case of Akinsete Syindicate v. Senior Inspector of Taxes. ${ }^{9}$ The case contains no analysis of the true tax effect of the transactions complained of: No evidence seems to have been put before the court as to this important distinction between avoidance and evasion or the doctrine of the sham transaction. Instead matters seem to have been dealt with on a very broad basis. This thoroughly unsatisfactory state of affairs is to be regretted. ${ }^{10}$

Tax avoidance has now been distinguished from tax mitigation but primarily for the purpose of interpreting a general anti-avoidance provision in New Zealand law, ${ }^{11}$ the distinction is that a tax avoidance plan does not affect the financial position of the taxpayer other than for the cost of the plan and the taxpayer is seeking to obtain a tax advantage without suffering the expense which Parliament intended should be suffered to quality for the advantage. Tax mitigation occurs when the expense is suffered.

The Nigerian tax system has a general anti-avoidance provision. ${ }^{12}$ And the legal basis for the judges' attitude towards avoidance schemes has to be found in interpreting the statutes and when applying the law to the facts.

The present position is that it is the duty of the courts to apply the legislation to the facts as determined. ${ }^{13}$ The court has power to strike down a transaction because it is motivated by tax avoidance although the question is always what is the true effect in law of the real transaction? ${ }^{14}$

\footnotetext{
7 Tiley and Collision 1997-1998 U.K. Tay Guide (Butterworths). Pp. 13-31.

8 See Roome v. Edwards [1979] BTC 546 at 661-565, [1979] BTR 261.1 Nigerian Tax Cases (NTC) 109

9 See Variables, The Offshare Taxation Review 1997, p.1

10 Per Lord Templeman in IRC, Challenge Corpn Ltd. [1986] STC 658 at 555. The New Zealand Provision was Income Tax Act 1976, 99 renders void for tax purposes arrangementsentered into for purpose of tax avoidance.

${ }^{11}$ See Section 21 GGTA; Section 18 CITA Section 17 PITD; Section 13 PPTA.

12 The task is one statutory construction of more accurately, statutory application, e.g.Nourse IJ in Fitzwilliam v. IRC [1992] STC 185 at 198) CA

${ }^{13}$ E.g. Lord Templeman in Ensing Tankers (Leasing) Ltd v. Stokes (1992) STC at 229a, HI.

${ }^{14}$ Fitzwillam v. IRC [1993]STC 502, HL
} 


\section{M.T. Abdulrazaq K.I. Adam}

In seeking the true legal effect the courts may treat a series of transactions as being one single transaction but only where it is possible realistically and intellectually to do so. ${ }^{15}$ The conditions for this power were laid down by Lord Oliver in the English case of Craven $v$. White: ${ }^{16}$

(1) that the series of transactions was, at the time when the intermediate transaction was entered into, preordained in order to produce a given result;

(2) that transaction had no other purpose than tax mitigation;

(3) that there was at that time no practical likelihood that the preplanned events would not take place in the order ordained, so that the intermediate transaction was not even contemplated practically as having an independent life; and

(4) that the preordained events did in fact take place. In these circumstances the court can be justified in linking the beginning with the end so as to make a single composite whole to which the fiscal results of the single composite whole are to be applied.

It could be said that the basic approach of the Nigerian tax system is still that laid down by Lord Tomlin in IRC v. Duke of Westminster ${ }^{17}$ that:

Every man is entitled if he can to arrange his affairs so that the tax attaching under the appropriate Acts is less than it otherwise would be. If he succeeds in ordering them so as to secure that result, then, however unappreciative the Commissioners of Inland Revenue or his fellow taxpayers may be of his ingenuity, he cannot be compelled to pay an increased tax.

It followed that a transaction which on its true construction was of a kind that would escape tax was not taxable on the ground that the same result could have been brought about by a transaction in another form which would have attracted tax.

\subsection{The Duke of Westminster Case}

In IRC $v$. Westminster the Duke covenanted to pay an employee a sum of $£$ 1:90 per week; the covenant was to last seven years whether or not he remained in the Duke's service. "The employee had a wage of $£ 3$ a week and he was told that while he would be legally entitled to the full $£ 3$ it was expected that in practice he would take only the balance of $£ 1.10$. The purpose of the scheme was to enable the Duke to deduct the payment in computing his total income for surtax. ${ }^{18}$ The scheme succeeded; the true construction of the document showed that these sums were income of the employee not under PAYE as an employee but as an annuitant, a charitable disposition.

In reaching this conclusion the courts were entitled to look at all the circumstances of this case, including the fact that the taxpayer had received a letter containing the expectations of the Duke already referred to. However, the court was also entitled to look at the fact that the legal right to payment would continue even though the employment ceased.

The majority of the court was not entitled to conclude that because this was a way in which money passed from employer to employee therefore it must be employment income if it was, in law, income under a charity. Lord Atkin, dissenting, thought this amounted to a contractual term and not just an expectation. ${ }^{19}$

\footnotetext{
$15 \quad$ [1988] STC 476 at 507.

[1936] AC 1, 19 TC 490

Sec payments are not now effective.

Sec Ensign Tankers (Leasing) Ltd v. Stokes [1992] STC 226 at 235, HL

LT (1996) STC 285
} 


\section{ANTI-AVOIDANCE LEGISLATIONS: ISSUES \& DOUBTS IN THE APPLICATION \\ OF TAX RULES IN NIGERIA}

The doctrine emerging from the Westminster case is that taxpayers and the tax authorities are bound by the legal results, which the parties have achieved even though this may be inconvenient for the tax authorities. This doctrine is still the formal position of tax law; the real question is what those legal results are. The court cannot disregard those facts just because of the tax avoidance purpose, which may have led the parties to create those facts in the first place. Sometimes those legal facts may be decisive of the fiscal consequences, as in the cases on the boundary between the contract of service and contract for services. Sometimes, as in Westminster, these legal facts while not in them self conclusive may point decisively in the direction of one particular tax consequence or characterization. Hence in Westminster the fact that, if the gardener had been dismissed or had left the Duke's employment he would still have been entitled to the sums under the covenant for the balance of the seven years period, swayed the majority to their conclusion. A more recent example is Reed v. Young ${ }^{20}$ in which the House Lords held that as the parties had created a limited partnership the courts were bound to give effect to a tax saving scheme based upon that legal structure.

The Westminster doctrine was sometimes expressed in the form that the court must look to the form of the transaction and not its substance. This formulation is, however misleading in that it tends to suggest that the form of a transaction, a matter which may be within the control of the taxpayer, will be conclusive for tax purposes. Often, however, the legal form used by the parties is not conclusive and here it is accepted that the court must look at the substance of the matter in order to determine the true tax consequence of the transaction in the legal form adopted by the parties.

Thus by looking at the substance it could conclude that this form attracted tax just as much as another. In these instances the court was not putting upon the transaction a legal character which it did not posses but was trying to discover the true character in tax law of the transaction entered into. ${ }^{21}$

So the court might hold that a that trade is carried on by a partnership even though the only document states that there was none, ${ }^{22}$ that a trader is still trading even though he says he is not ${ }^{23}$ or that the person claiming to trade is simply the means by which he trade is carried on by someone else. ${ }^{24}$

In such contexts the documents cannot be used to deny proven facts. Where, however, both the facts and the legal arrangements point in the same direction, the court might not disregard them. ${ }^{25}$

It follows that the name given to a transaction by the parties concerned did not necessarily decide the nature of the transaction. ${ }^{26}$ So a description of a series of payments as an annuity or a rent charge does not determine their character. ${ }^{27}$

The Westminster doctrine was highly regarded by the United Kingdom Inland Revenue, not least because it was applied in their favour when the taxpayer has carried out a transaction in manner less than wholly tax-efficient. ${ }^{28}$ However, the doctrine was always subject to limitations. First the court might conclude that the transaction was a sham, that the acts done were intended to give the appearance of creating legal rights different from those which were actually created. Such schemes still fail for the simple reason that the tax falls to be levied on

Goerge MR in IRC v.

Fenson v. Johnstone (1940) 23 TC 29

I and R O’ Kane \& Co. Ltd. v. IRC (1922) 12 TC 303

Firestone Tyre and Rubber Co. Ltd. v. Lewlin [1957] 1 AII ER 561, 37 TC 111

Ransom v. Higgs (1974) 3 AII ER 949, 1197 STC 539,

Secretary of State in Counsil of India v. Scoble (1903) AC 299, 4 TC 618.

IRC v. Land Securities Investment Trust (1969) 2 AH ER 430, 45 TC 495.

E.g. IRC v. Fleming \& Co. (Machiners) Ltd (1951) 33 TC 57 at 62.

(1984) STC 153, [1984] 1 AII ER 50 


\section{M.T. Abdulrazaq K.I. Adam}

the basis of the actual legal rights created. This argument although frequently advanced by there venue did not meet with great success.

However, the new approach based on the decision of the House of Lords in Furniss $v$. Dawson $^{29}$ encouraged the courts to give the Revenue occasional glimpses of success. So in Sherdley v. Sherdley, ${ }^{30}$ Sir John Donaldson MR thought that an order to pay school fees to a school on behalf of a child and made at the suit of the parent against whom the order would have been made would be a sham.

This use of the sham argument is highly questionable and probably erroneous. The decision was later reversed by the House of Lords, but withour discussion of this point. ${ }^{31}$ Since then the orthodox narrow definition of a sham transaction has prevailed. ${ }^{32}$

Second, Parliament has created exceptions; it has passed a number of measures enabling the Revenue to tax transactions, which are widely defined unless the taxpayer can show that there was no tax avoidance motive.

Third it is probably right to distinguish the Westminster doctrine just outlined from a Westminster approach which tended to look not too unfavourably on attempts to avoid tax. This approach has wavered in recent years as the courts have been presented with highly artificial schemes such as that in Ramsay and only slightly less artificial ones such as Furniss v. Dawson. The courts have, however, been willing to uphold even highly artificial schemes as can be seen in Fitzwilliam v. IRC.

Finally, although the courts have long recognized that tax avoidance is lawful, it is not yet a virtue and so in Re Weston's Settlement ${ }^{33}$ the English Court of Appeal declined to approve a variation of trust where the only advantages accruing to the beneficiaries on whose behalf they were being asked to approve the variation were financial, stemming almost exclusively from the saving of tax. Similarly in Sherdley v. Sherdley the Court of Appeal declined to make an order for financial provision of a child when the only reason for that order would have been the tax saving; this was reversed by the House of Lords but is an indication of a general attitude. ${ }^{34}$

\section{The Nigerian Position}

The basic approach of the Nigerian tax system which follows the principle laid down in the Duke of Westminster case was stated by Bairamian JSC in the case of Akinsete Syndicate v. Senior Inspector of Taxes ${ }^{35}$ that:

It is trite that a person may use lawful means to avoid tax; what he may not

do is to try to evade it. What he does should be genuine... not merely a verluo hide or dissemble the reality of things.

In the case, an agreement was signed between one Chief G.M. Akinsete, the licensee of certain timber extraction rights and another company, Coast timber Company Limited, for the extraction, management and sale of the timber of the land over which the licensee had concession. The agreement permitted the sharing of profits between the two parties and it was signed in June, 1953.

Another supplemental agreement was signed between the licensee (Chief Akinsete), the company and a joint licensee made up of four individuals in January, 1959. The supplemental agreement which created a partnership between the licensee and the joint licensee and merged the interest of the licensee and the joint licensee into one, provided that the interests and

29 (1986) STC 266 at 273. Balcombe, LJ disagreed (at 278) and Neill, LJ made no comment.

30 (1987) STC 217.

31 See e.g Lord Goff in Ensign Tankers (leasing) Ltd. V. Stokes (1992) STC 226 at 245h, HL.

32 (1969) 1 Ch 223, (1968) 1 All ER 720.

331987 STC 217.

341 NTC 110.

35 (1976) NTC 109. 
benefit of the licensee under the first agreement "now belongs" to the joint licensee called "G.M. Akinsete Syndicate".

The respondent assessed Chief Akinsete to tax for the income accruing to him out of the timber business for the accounts of the year ended 1958. The appellant contended that because of the words "now belongs" in the second agreement, the income and other benefits accruing to Chief Akinsete had reverted to the joint partnership since the date of the first agreement in 1953 and that for that reason Chief Akinsete could not be taxed on the income of the timber business accruing in 1958.

It was also argued by the appellant that the partnership had existed as a matter of fact since the signing of the first agreement although the partnership agreement itself was signed only in 1959. The respondent contended that there was no partnership in fact and in law by the year 1958, on which the assessment was based, and that if there was any, the transaction was artificial and fictitious and should be disregarded in accordance with section 15 of the Income Tax Law of Western Nigeria, 1959.

It was found on evidence that the share of profits of the partnership was paid into the account of Chief Akinsete who withdrew as he pleased and handed out money as he pleased. It was held that:

1. The existence of the syndicate before 1959 was not proved. The supplemental agreement of 1959 only created the partnership on that date.

2. The taxpayer was rightly assessed as the bona fide owner of the income accruing to him from the venture in 1958.

3. Appeal dismissed.

\subsection{Anti-Avoidance Legislation in Nigeria}

The status of the Akinsete principle was thrown into some doubt by a series of antiavoidance legislations beginning with the now repealed section 14 Income Tax Management Act (ITMA) 1961 which provides that:

Where a tax authority is of the opinion that any disposition is not in fact given effect to or that, any transaction which reduces or would reduce the amount of any tax payable is artificial or fictitious, the tax authority may disregard the disposition or direct that such adjustments shall be made as respects the income of an individual, an executor or a trustee, as the tax authority considers appropriate so as to counteract the reduction of liability to tax effected, or reduction which would otherwise be effected by the transaction.

and reaching its high water mark in the provisions of Section 22 of Company Income Tax Act 2004, ${ }^{36}$ Section 20 Capital Gains Tax Act $2004^{37}$ and section 17 of Personal Income Tax Act $2004^{38}$ which simply restated and re-enacted the repealed section variously. The Supreme Court of Nigeria has so far refused to give a judicial interpretation to the meaning of "artificial or fictitious transaction", first, the case of Federal Board of Inland Revenue v. $\mathrm{Nasr}^{39}$ the Supreme Court stated that:

At one stage in the High Court, the Board wished to submit that the transaction should be disregarded as an artificial one within the Income Tax Management Act but as this point has not been raised before the commissioners, the High Court refused to allow it to be raised on the further

\footnotetext{
See Cap C. 21, Laws of the Federation of Nigeria, 2004

See Cap C. 1, Laws of the Federation of Nigeria, 2004

38 See Cap P. 8, Laws of the Federation of Nigeria, 2004

391 NTC 115, 116.
} 


\section{M.T. Abdulrazaq K.I. Adam}

appeal and no evidence was called which could have justified such a finding.

Secondly, in the case of Aboud v. Regional Tax Board, ${ }^{40}$ the appellant brought an action in the High Court of Western Nigeria, asking for a declaration (i) that he was not liable to pay tax for the year of assessment 1962/1963 on property at No. 61A Lebanon Street, Ibadan on the ground that the property was not his property from which he derived an income and (ii) that the assessment notice served on him was null and void.

His statement of claim made it clear that what he was objecting to was the decision of the Board to treat his action in conveying the property concerned to his wife as an artificial or fictitious transaction or disposition in accordance with Section 15 of the Income Tax Law (cap. 48), and the pleading concluded by saying that this decision was wrong in law and therefore null and void.

The Supreme Court was urged that it was desirable to have an authoritative interpretation of Section 15 of the Income Tax Law (cap.48), the court stated that the appeals provided for by the law itself afford the means of securing such an interpretation and there is no reason for departing from the ordinary practice of the courts as regards declaratory judgments. The Supreme Court further held that, as regards the first part of the declaration sought in this case, if the court were to hold that the Board had been right it would add nothing to an assessment which has already become final and conclusive; if the court were to declare that the Board had been wrong it would take nothing from the assessment and would merely lead to confusion.

On the pleadings, the court held that the second part of the declaration sought is consequential on the first and if the court declines to consider one it cannot consider the other.

However, while emphasizing the significance of the anti-avoidance legislation it must be carefully stressed that the Akinsete principle was still law and had not been over-ruled. It may be distinguished like the Duke of Westminster's case on the grounds that it:

was about a simple transaction entered into between real persons, each with a mind of his own.... The kinds of tax avoidance schemes that have occupied the attention of the courts in recent years, however, involve interconnected transactions between artificial persons, limited companies without minds of their own but directed by a single master mind. ${ }^{41}$

The importance of this approach is, first, that it enables one to explain the existence of commercial reality and secondly that it is much wider and more flexible than the simplealmost mechanistic- excision approach of the anti-avoidance provisions. ${ }^{42}$

\subsection{Judicial Reluctance in Interpreting the Anti-Avoidance Legislations}

It is important for three reasons. First, it establishes that there is no mechanistic time period after which transactions cannot be linked.

The second is that the cases underline the point that while the effect of the legislation being applied is to make the whole matter one transaction for tax purposes, that does not mean that the tax authorities can defeat it; the court still has to see whether the government position is realistically and intellectually defensible. The third reason is that it shows some signs of going back to the enduring effect argument used in the Duke of Westminster's case and stated in Akinsete case that the courts will not disregard the enduring effects of what the parties have done when applying the anti-avoidance legislation.

\section{$40 \quad 1$ NTC 125.}

41 Ramsay v. IRC [1982] STC 30 at 32. Sec Gammic, Strategic Tax Planning, Part D, p.17.s

42 For a general account of US doctrine see Bittker Federal Taxation of Income Estates and Gifts, especially Chapter 4. For example of skepticism see Rice, 51 Mich I.R at p. 1021; see also Tiley [1987] BTR 180 and 220, [1988] BTR and 108. For examinations of the UK cases from a US perspective see Popkin [1991] BTR and Kolb Hastings International and Comparative Law, Review Vol. 15, p. 159. 
These cases show an ebb and flow of judicial opinion in determining the fiscal consequences of the facts which the parties have created - the problems of characterization - and underline how difficult that task can be especially when the courts are presented with highly artificial schemes. Faced with such problems the courts frequently like to emphasise the need to have regard to the reality of the situation or, less frequently, its substance.

An example of this is the decision of the English House of Lords in Ensign Tankers (Leasing) Ltd. v. Stokes, which embodies a matter of approach rather than a rule. This approach allows (and probably requires) the courts to examine the reality of the situation reaching the correct tax characterisation of the facts. This may mark the reconciliation, at least at the formal level, of the New Approach with the Westminster doctrine since, of course, under that doctrine the labels given by parties did not matter and the court have long been required to determine the true legal character of the transactions. What may matter just as much is the emphasis given by Lord Templeman to the obligation of the courts to ensure that the taxpayer does not pay too much tax, not just too little. ${ }^{43}$ Neither the taxpayer nor the state should be deprived of the fiscal consequences of the taxpayers' activities properly analysed.

In the Ensign case the question was whether the taxpayer was entitled to capital allowances for expenditure incurred on the introduction of a film. The taxpayer company, E, which as may be surmised from its full name had little to do with world of films, formed a limited partnership, V, with some other companies to provide finance for a film to be directed by John Huston and starring Michael Caine. The film was also to feature such soccer legends as Bobby Moore and Pele and was called "Escape to Victory". V put up 25 percent of the estimated cost of the film $(\$ 3.2 \mathrm{~m}$ out of $\$ 13 \mathrm{~m})$ the balance being provided by a non-recourse loan made to the general partner by the film company, L, a part of the Lorimar group with whom the partnership had no other connection. The partners, including E, had no personal liability. The film company was also to be responsible (on similar terms) for any cost overrun. The receipts from the film would be divided 25 percent to the limited partnership and 75 percent to the film company until the loan was paid off and then to paying off the loan to cover the cost of the overrun of costs $(\$ 1 \mathrm{~m})$ and any interest on such loans.

What $\mathrm{V}$, and therefore $\mathrm{E}$, hoped to achieve was that in return for putting up less than ${ }^{44} 25$ percent of the cost, they would be able to receive capital allowances on the total cost of production since at that time the rate of corporation tax was 50 percent and the rate of the relevant allowances was 100 percent of the expenditure. The Crown attack was not less extreme: this was not a trading transaction and therefore was not entitled to any allowance at all, not even the expenditure of $\$ 3.25 \mathrm{~m}$ which had been incurred.

The commissioners held that this was not trading transaction since V's paramount object of the transaction was to obtain a fiscal advantage. This was reversed by Millett $\mathrm{J}$ who held inter alia that the taxpayer was trading and that the correct test was an objective one; the full allowance was therefore due. ${ }^{45}$ The Court of Appeal reversed Millet J. ${ }^{46}$

The House of Lords, reversing the Court of Appeal, produced a new solution. This was a trading transaction. $\mathrm{V}$ and therefore $\mathrm{E}$ were entitled to capital allowance on the expenditure actually incurred. However, the expenditure which had been incurred was $\$ 3.2 \mathrm{~m}$ not $\$ 14 \mathrm{~m}$. This conclusion involved a close analysis of the fact to determine their true legal effect. The scheme would not be allowed to have the apparently magical effect of creating expenditure for tax purpose of $\$ 14 \mathrm{~m}$ while incurring real expenditure of only $\$ 3.25 \mathrm{~m}$. The expenditure of the remaining $\$ 10.75 \mathrm{~m}$ was really incurring by $\mathrm{L}$. The House of Lords proceeded to penalize

\footnotetext{
[1992] STC 226 at 236

After taking account of the overrun which was also financed by non-recourse loan.

45 [1989] STC 705

$46 \quad[1991]$ STC 136
} 


\section{M.T. Abdulrazaq K.I. Adam}

the taxpayers for attempting a scheme which brought no credit on their advisers ${ }^{47}$ by making them pay all the costs of the appeal. ${ }^{48}$

The importance of this case lies in its return to the true legal nature of the transaction and the emphasis on ensuring that the taxpayer did not end up paying too much tax: The presence of a tax avoidance purpose does not means that a scheme can simply be disregarded. One must, as Young v. Phillips ${ }^{49}$ shows, find the real transaction.

Before turning to some of the detailed issue emerging from these cases it is time to face the problem of authority- what is the basis for what the courts have been doing? If the matter is one of statutory interpretation in cases involving tax avoidance schemes then the courts have to explain where the authority for such a rule comes from. If, on the other hand, it is simply one of determining the correct tax characterization of the facts with which the courts have to deal then the problem of authority is solved but at the cost of opening up a very different form of rule. In the new form the rule is not one concerned exclusively with tax avoidance. In the Furniss v. Dawson ${ }^{50}$ and Craven v. White ${ }^{51}$ cases the issue is not one of countering avoidance schemes but one of defining the circumstances under which a transfer from $\mathbf{A}$ to $\mathbf{B}$ followed by one from $\mathbf{B}$ to $\mathbf{C}$ could be treated as a single transfer from $\mathbf{A}$ to $\mathbf{C}$ or as an artificial transaction.

At one time it appeared that the nature of the quest might be resolved by new litigation. In Whittles $v$. Uniholdings $2 t d .{ }^{52}$ The taxpayers had taken out a dollar bank loan to finance a sterling acquisition. In order to reduce their exposure to currency exchange risks the taxpayer also took out a forward contract with the same bank to buy the same number of dollars at the end of the period of the loan at a fixed sterling price. The issue was whether this will be treated as one single transaction or as two; in the latter some absurd but well known fiscal consequence accrue. The Revenue argued that the transactions should be taxed separately; the taxpayer that they constituted a single composite agreement between it and the bank under which it could not deal with forward contract without the consent of the bank.

Sir John Vinelott held that there was a single composite transaction because that was the true contractual effect of the arrangement. In the court of appeal the Crown argued that there were two transactions whether or not there was a contractual nexus. Aldous LJ would have dismissed the appeal but was outvoted by Nourse LJ and Sir John Balcombe.

For Nourse LJ what mattered was that but for the Ramsay case which he persisted in calling "the fiscal nullity doctrine", he would have attached great weight to the House of Lords decision in Aberdeen Construction Group Ltd. V. IRC. ${ }^{53}$ He then said:

If that would have been the position in the present case before the emergence of the Ramsay principle, has it now changed in any way? Clearly, it has not. At this point it is necessary to assure that there was no contractual link between the loan and forward contracts, that being the only footing on which the principle would have a part to play. Decision subsequent to Ramsay, itself, especially Craven v. White (1988) STC 476, (1986) AC 398, have shown that the principle is still in a process of development. Differences of opinion amongst their Lordship in Countess Fitzwilliam v. IRC (1993) STC 502, (1993) I WLR 1189 have shown that it is still uncertain where it has got to and to where it may go next. One thing

\footnotetext{
47 [1992] STC 266 at 234

48 [1992] STC 266 at 244

49 [1984] STC 520

50 [1984] LAII ER 530

${ }^{51}$ [1989] A.C. 398

52 [1993] STC 671, 767

53 (1978) STC 127
} 
may, however, be asserted without fear of contradiction. While... the principle, ... one of statutory construction, is capable of being invoked by a taxpayer in certain circumstances, it is clear that if it had never before been thought of, it would not have been invented to enable the company to succeed in this case. More decisively still, it could not attributed to two transactions with no contractual link between them fiscal consequences different from those resulting from two transactions between which there was such a link

Almost every sentence of this paragraph is worthy of close study. The oddity is that the English Court of Appeal then refused leave to appeal to the House of Lords. If ever a case demanded that their lordships resolve the problems they have created, it is this one. With a major unresolved issue as indicated by Nourse LJ and the lower judges split 2-2, the present impasses is unfortunate ${ }^{54}$.

\section{$5 \quad$ Issues and Doubts - Elements of the Anti- Avoidance Legislation}

A number of questions arise:

1. Will the Nigerian course accept that the presence of any commercial motive, however slight, will exclude the application of the legislation? An affirmative answer is suggested by lord Brightman's formulation and Nigeria case law does not yet suggest that the legislation will be excluded only if the commercial motive is the main one. This issue was raised in Craven v. White ${ }^{55}$ where it was held that where there was two courses of action genuinely open to the taxpayer and actively being considered by him, one of which would have entitled him to use the deferral under what is now TCGA 1992, s136 despite Furniss v. Dawson, ${ }^{\mathbf{5 6}}$ and the other of which would not, the revenue could not use Furniss v Dawson to deprive him of the deferral as there was a sufficient commercial motive at the time of the disposal: this aspect of the case was not developed in the House of Lord. ${ }^{57}$ However in the speeches there are many references to transactions which have no commercial purpose other than the avoidance of tax.

In Ensign Tanker (Leasing) Ltd. vs. Stokes in the Chancery Division millet J held that the court could not disregard the existence of a limited partnership where it was commercially essential to have some structure to regulate the relationship of the parties. ${ }^{58}$

2. What is meant by a commercial motive? Is "commercial" simply a synonym for "nontax" so that, for example, a wish to protect the family wealth by the creation of a protective trust will be effective even though some tax sheltering will result? Likewise, is a wish to use a tax shelter company so as to be subject to external company law, which permits loans to directors, a sufficient "commercial" purpose?

There may be major difficulties about a case which two partners go in for the same transaction where one is motivated purely by the thought of saving tax but the other has no raise money to pay maintenance to an ex-spouse or is motivated by some wish to preserve the business. In Shephered v. Lyntress Ltd. a need to avoid a pre-emption agreement over shares was held to be a sufficient commercial justification. ${ }^{59}$

\footnotetext{
54 .Whittles v. Uniholdings Ltd (No.3) (1996) STC 614, CA, reversing (1995) STC 185.

(1985) STC 531 followed in Baylis v. Gregory (1986) STC 22, (1986) 1 All ER 289, and IRC v. Bowater property development ltd. (1985) STC 783.

56 (1984) 1 All ER 530, (1984) STC 153.

${ }^{57}$ However Lord Oliver said that was a bona fide commercial; purpose (1988) STC at 510). (1989) STC 705 at 770; he also said that it was logically impossible to conclude that the partnership was trading and that the transaction entered into had no commercial purpose (at 771) however Lord Brightman's text talks of no commercial effect, not no commercial purpose the revenue did not a appeal against this part of the judgment; (1991) STC 136 at 149.

58 [1992] STC 226.

59 [1989] STC 617 at 650
} 


\section{M.T. Abdulrazaq K.I. Adam}

3. What taxes are affected by this legislation? So far the Nigerian cases have involved income tax or their corporate equivalent. It could be argued that stamp duties are not affected since those are taxes on instruments not transactions; however it can be countered that the legislation is ideally designed to counter avoidance schemes because it requires a broad view of the transaction which is being carried out by the instrument ${ }^{60}$ if the doctrine is simply one of characterisation of the facts all taxes are open to its applications.

4. What is the role of the anti-avoidance legislation? Following precedents in other countries which have had to wrestle with general anti-avoidance provision it can be argued that the courts should not allow the use of the legislation if the taxpayer has simply carried out a straightforward transaction, falling exactly within the purpose and ambit of a provision of the tax legislation. ${ }^{61}$

Cases such as this may fall to be dealt with as having a sufficient commercial motive or as single step transactions. However, in relation to transactions within a group of companies, it has been held that the purpose of the express provision is to allow assets to be moved within the ring fence without any fiscal consequence and that this purpose should not be defeated. ${ }^{62}$

More difficulty will be met where the taxpayer can bring himself within an express statutory defence. Will this exclude the legislation? It is though that it should. ${ }^{63}$

5. Who can invoke the anti-avoidance legislation? This problem is now the fundamental one awaiting solution. Can the courts use it to undo statutory absurdities? ${ }^{64}$ There is a suggestion in Pattison v. Marine Midlord Ltd. that the courts can invoke it to counter an attempt by the Government to "invent an artificial accounting scheme which serves no purpose and is designed solely to create a liability to tax. ${ }^{65}$

If, as in the current democracy, the matter is simply one of statutory application, there seems to be no logical reason why the Nigerian Courts should not be able to invoke the antiavoidance legislation suo motu

6. Can the anti-avoidance legislation be invoked to change the timing or the location of a transaction $?^{66}$ Thus suppose that I am about to emigrate ( $1^{\text {st }}$ January) and wish to postpone a CGT disposal until after I have ceased to be resident in the Nigeria - so avoiding CGT- and yet require the certainty of the sale. I therefore agree that my purchaser shall have an option to buy on any day in January and I have the right to insist on a sale during February. This agreement is made in November but CGT timing rule will make the date of the disposal that where the contract become unconditional.

One may also note the view of one judge that when a disposal by A to B is followed by one from $\mathrm{B}$ to $\mathrm{C}$ and this disposal is one preordained transaction that transaction should be treated as taking place at the time of the first step. ${ }^{67}$

7. How do you identify an artificial or fictitious transaction? English Cases have reiterated the strict test laid down. ${ }^{68}$ In Hatton v. IRC ${ }^{69}$ Chadwick $\mathrm{J}$ said that a preordained series of transactions meant nothing more than a series transactions which had been preplanned to take place in a specific order in circumstances in which there was, at time the first

\footnotetext{
60 See Simon's Weekly Tax Intelligence 1997, p. 1057. The principle that liability to stamp duty follows the true legal effect of the document is not contradicted.

61 As was stated by Walton J in Reed v. Nova Securities Ltd. At first instances [1962] STC 724.

62 Vinclott J in News International Plc v. Shepherd [1982] STC 724.

63 [1985] STC 584 at 647.

64 [1980] STC 341, 53 TC 304, Ang v. Parrish.

65 [1983] STC 269 at 276, CA See also vinclott J in Bird v. IRC [1985] STC 584 at 647

66 See the discussion by Gammie in Strategic Tax Planning Part D, p. D35

67 See Vinclott J in Shephered v. Lyntress (1989) STC 617 at 650

68 E.g Fitzwillam v. IRC [1993] STC 502, HL and Hatton v. IRC [1992] 64. STC 140 ,both dealing with IHT and shephered v. Lyntress [1989] STC 617.

69 [1992] STC 140
} 
transaction was entered into, no practical likelihood that the remaining transactions would not take place in that order. There was, he said, no requirement of control over the decision to take the subsequent steps. Similarly in Fitzwilliam v. IRC there was a preordained scheme despite the fact that the clients were kept in dark as to totality of the scheme and that one of them was separately advised after step $3 .^{70}$ Is a conclusion by the tax authorities that a series of transactions constitutes an artificial or fictitious transaction a question of fact or of law?

In such cases.... the Commissioners should find the facts and then decide as a matter (reviewable) of law whether what is in issue is a composite transaction, or a number of independent transactions.... ${ }^{71}$

"... the correct approach in this type of case, where inferences have to be drawn, is for the commissioners to determine (infer) from their findings of primary fact, the further fact whether there was a single composite transaction in the sense in which I have used that expression, and whether that transaction contains steps which were inserted without any commercial or business purpose apart from a tax advantage; and for the appellate court to interfere with that inference of fact only in a case where it is insupportable on the basis of the primary facts so found ${ }^{72}$

In effect the question is essentially one of law. ${ }^{73}$

\section{Conclusion}

Conclusions may now be firmer as a result of the Akinsete principle and the guidance of the English Courts. For the moment we have a test based on "no practical certainty" or "no real likelihood" that the second step will not follow the first. ${ }^{74}$ It is, moreover, consistent with the Nigerian notions of the interpretations, and application of tax statutes.

Second, anti-avoidance legislation is not to allow the tax authorities to under, transactions simply because they have a tax avoidance motive. The courts are overtly fearful of creating a situation which would allow the tax authorities to strike down any transaction entered into for the avoidance of tax. ${ }^{75}$

Third, it is hard to resist the conclusion perhaps a little cynically, that the tax authorities cannot tolerate judicial interference in this matter and may feel the need for more legislation, as has occurred most recently in Canada or, alternatively, retaliate with even more and more detailed legislation and regulations replete with anti-avoidance clause. Hopefully, a clearer picture on this should emerge before the year 3000 .

\section{SELECTED REFERENCES}

[1] Abdulrazaq M.T., Legislation against Tax Avoidance: The Nigerian Experience, Justice: Journal of Contemporary Legal Problems, Vol.2 No.9, pp.33-46, 1991.

[2] Abdulrazaq M.T., Nature of Tax Evasion and Avoidance, Nigerian Financial Review, Vol.4, No.3, pp. 65-74, 1992.

[3] Tiley and Collison, UK Tax Guide, Butterworths, 1997-1998, 13-31.

\footnotetext{
${ }^{70}$ Lord Browne-Wilkson[1993] STC 502, HL, at 536

${ }^{71}$ Ramsay v. IRC [1981] STC 174 at 180, [1982] AC 324.

${ }^{72}$ Furniss v IRC [1984] STC 153, [1984] AC 474.

${ }^{73}$ Fitzwilliam v. IRC [1993] STC 502, HL, at 515.

${ }^{74}$ This test was applied in shepherd v. Lyntress Ltd. [1989] STC 617. There Vinelott rejected a "frontal assault on the ability of a group to hive down loses into a subsidiary and to sell the subsidiary to another willing to purchase it so that it can set its own gains against the losses." (at 650).

75 See e.g. Piggot v. Stainless investment Co Ltd. [1995] STC 114.
} 